Jurnal Ilmu Sosial dan Pendidikan (JISIP)

Vol. 5 No. 3 Juli 2021

Terakreditasi Peringkat 5 (No. SK: 85/M/KPT/2020)

e-ISSN : 2656-6753, p-ISSN: 2598-9944

DOI: 10.36312/jisip.v5i3.2199/http://ejournal.mandalanursa.org/index.php/JISIP/index

\title{
Inkonstitusionalitas Pajak Bumi dan Bangunan Sektor Pertambangan Mineral dan Batubara di Indonesia
}

\author{
Argo Trinandityo \\ Magister Ilmu Hukum, Universitas Indonesia
}

\begin{tabular}{l}
\hline Article Info \\
Article history: \\
Article Reseived : 09 July 2021 \\
Publication: 16 July 2021
\end{tabular}

Keywords:

Pajak Bumi dan Bangunan, Mineral dan Batubara, Konstitusi UUD 45

\begin{tabular}{l}
\hline Article Info \\
Article history: \\
Artikel diterima : 09 Juli 2021 \\
Publikasi : 16 Juli 2021 \\
\hline
\end{tabular}

\section{Kata Kunci: \\ Land and Building Tax, Mineral and Coal, Constitution UUD 45} \begin{abstract}
Pajak mencerminkan keikutsertaan dan kegotongroyongan masyarakat di bidang pembiayaan pembangunan. Sebagai sumber utama penerimaan negara, penerimaan perpajakan selalu mendapatkan fokus dan kedudukan yang istimewa dalam hukum, yang mana selalu mendapat prioritas pelunasan di antara kewajiban-kewajiban seorang warga negara terhadap hal-hal lainnya. Indonesia merupakan negara hukum (rechtstaat), dan bukan negara kekuasaan (machtstaat), sehingga hukum harus selalu menjadi pedoman utama dalam pelaksanaan kehidupan bernegara. Undang-Undang Dasar Negara Republik Indonesia 1945 (UUD 45) sebagai konstitusi negara membatasi kekuasaan Pemerintah sebagai penyelenggaraan negara, termasuk perpajakan. Sehingga peraturan mengenai pajak dan pungutan lain yang bersifat memaksa untuk keperluan negara diatur dengan Undang-Undang. Sebagai akibatnya, pajak yang tidak diatur dengan undang-undang adalah inkonstitusional. Pajak Bumi dan Bangunan Sektor Pertambangan untuk Mineral dan Batubara (PBB Minerba) masih mengacu kepada Undang-Undang Pajak Bumi dan Bangunan, yang sesungguhnya tidak sesuai dengan karakteristik PBB Minerba itu sendiri. Dan hingga kini PBB Minerba belum diatur oleh Undang-Undang sesuai amanat Amandemen ketiga UUD 45 tersebut
\end{abstract}

\begin{tabular}{l} 
Tax shall reflect the community cooperation and participation in \\
order to fund the nation's development. As the main source of the \\
country's income, tax payment always has special treat from the law, such \\
as the priority payment from the certain people (in example debtor) before \\
any other payment obliged to them. Indonesia as a Nation of Laws \\
(rechtstaat), and not a Power State (machtstaat), therefore shall to give law \\
as the main guidance for the nation in every action. The Undang-Undang \\
Dasar Negara Republik Indonesia 1945 (UUD 45) as the Constitution \\
shall limit the Government power, including the power to tax. Therefore, \\
the regulation related to tax and any levy imposed for the country must be \\
regulated by a Law/Act. As the consequences, tax without a Law will be \\
unconstitutional. Indonesia Land and Building Tax for Mineral and Coal \\
Mining Sector (PBB Minerba) still referring to Law of Land and Building \\
Tax, which has very distinguished character with the PBB Minerba itself. \\
Until now, PBB Minerba have not regulated by a certain Law/Act as \\
obliged by the third amendment of constitution UUD 45. \\
\hline This is an open access article under the Lisensi Creative Commons Atribusi-BerbagiSerupa 4.0 Internasional
\end{tabular}




\section{PENDAHULUAN}

Konstitusi Undang-Undang Dasar Negara Republik Indonesia Tahun 1945 (UUD 45) menempati posisi tertinggi dalam hierarki Peraturan Perundang-Undangan di Indonesia. Hal tersebut ditegaskan kembali dalam Pasal 7 ayat 1 huruf a Undang-Undang Nomor 12 tahun 2011 tentang Pembentukan Peraturan Perundang-Undangan (UU 12/2011). Posisi tersebut menimbulkan implikasi bahwa setiap peraturan perundang-undangan yang ada di Indonesia tidak boleh bertentangan dengan UUD 45, dan sebagai akibatnya dalam hal terjadi pertentangan, maka peraturan perundang-undangan tersebut tidak memiliki kekuatan yang mengikat.

Dalam hal perpajakan, konstitusi UUD 45 telah mengatur hal tersebut dalam Pasal 23 A yang menyatakan bahwa "Pajak dan pungutan lain yang bersifat memaksa untuk keperluan negara diatur dengan Undang-Undang." Ketentuan tersebut mengamandemen ketentuan dalam naskah awal Pasal 23 ayat 2 UUD 45 yang menyatakan bahwa "Segala pajak untuk keperluan negara berdasarkan undang-undang." Perubahan tersebut mengakibatkan bahwa suatu Pajak dan pungutan lain yang bersifat memaksa harus terlebih dahulu diatur dengan suatu Undang-Undang, baru kemudian dapat berlaku mengikat kepada masyarakat selaku Wajib Pajak (WP). Hal tersebut berbeda dengan rumusan sebelum amandemen UUD 45 yang hanya mensyaratkan UndangUndang sebagai dasar penetapan suatu pemungutan pajak, sedangkan untuk pengaturannya dapat dilakukan oleh peraturan perundang-undangan yang secara hirarkis berada di bawahnya.

Rumusan Pasal 23 A UUD 45 tersebut sejalan dengan sifat dari pajak yang menganut asas representasi, dimana Undang-Undang adalah produk hukum dengan hierarki tertinggi yang melambangkan adanya kesepakatan antara lembaga eksekutif dan lembaga legislatif yang merupakan representasi dari rakyat Indonesia sesuai Sila keempat Pancasila (permusyawaratan perwakilan). Representasi tersebut menjadi sangat penting artinya karena di dalam konstitusi UUD 45 negara juga memiliki tugas untuk melindungi segenap bangsa Indonesia dan seluruh tumpah darah Indonesia, oleh karena itu negara tidak boleh menjadi tirani bagi rakyatnya sendiri.

PBB Minerba merupakan suatu bentuk pajak yang yang belum diatur oleh Undang-Undang sesuai dengan amanat UUD 45 amandemen ketiga. Walaupun hingga kini masih menggunakan terminologi Pajak Bumi dan Bangunan, sesungguhnya PBB Minerba memiliki karakteristik yang tidak konsisten bahkan tidak sesuai dengan karakteristik Undang-Undang Pajak Bumi dan Bangunan, yang akan saya bahas lebih jauh dalam tulisan ini.

Mengingat pembahasan ini mengenai kedudukan suatu aturan hukum terhadap konstitusi negara, maka saya akan membahas dari sisi peraturan perundang-undangan yang berlaku di Indonesia, mulai dari Undang-Undang Dasar Negara Republik Indonesia Tahun 1945 (UUD 45), Undang-Undang Nomor 12 tahun 1985 tentang Pajak Bumi dan Bangunan (UU PBB) beserta perubahannya (UU 12/1994 atau UU PBB perubahan), Undang-Undang Nomor 4 tahun 2009 tentang Pertambangan Mineral dan Batubara (UU Minerba) beserta perubahannya UU Nomor 3 tahun 2020 (UU Minerba perubahan), Undang-Undang Nomor 28 tahun 2009 tentang Pajak Daerah dan Retribusi Daerah (UU PDRD), Keputusan atau Peraturan Menteri Keuangan hingga Peraturan Direktur Jenderal Pajak yang relevan dengan pembahasan ini, yang akan dianalisa dengan menggunakan penalaran yuridis untuk memberikan argumentasi yuridis.

\section{KAJIAN PUSTAKA}

\subsection{Mengenal PBB Minerba}

PBB Minerba merupakan Pajak Bumi dan Bangunan yang dibebankan terhadap pelaku usaha pertambangan mineral dan atau batubara, dengan asumsi bahwa mineral dan atau batubara tersebut merupakan hasil yang diperoleh dari dalam bumi. Mengapa saya katakan hal tersebut sebagai asumsi? Karena baik dalam rumusan teks Undang-Undang Nomor 12 tahun 1985 tentang Pajak Bumi dan Bangunan (UU PBB) maupun perubahannya yakni Undang-Undang Nomor 12 tahun 1994 (UU PBB perubahan), tidak disebutkan secara jelas mengenai terminologi maupun keberadaan PBB Minerba tersebut. Hanya Pasal 30 dari UU PBB tersebut yang sedikit menyinggung mengenai pertambangan, akan tetapi hanya 
membahas dalam kaitan kewajiban pembayaran IPEDA (Iuran Pembangunan Daerah). Sehingga jenis PBB Minerba jelas tidak diatur sebagai obyek pajak dalam UU PBB ataupun dalam UU PBB perubahannya.

PBB Minerba secara spesifik baru muncul dalam Keputusan Menteri Keuangan Nomor 1003/KMK.04/1985 tentang Penentuan Klasifikasi dan Besarnya Nilai Jual Obyek Pajak Sebagai Dasar Pengenaan Pajak Bumi dan Bangunan, yang kemudian diubah oleh Keputusan Menteri Keuangan Nomor 22/KMK.04/1986, Keputusan Menteri Keuangan Nomor 1324/KMK.04/1988, Keputusan Menteri Keuangan Nomor 387/KMK.04/1989, Keputusan Menteri Keuangan Nomor 1147/KMK.04/1991, Keputusan Menteri Keuangan Nomor 174/KMK.04/1993, Keputusan Menteri Keuangan Nomor 196/KMK.04/1994, Keputusan Menteri Keuangan Nomor 273/KMK.04/1995, Keputusan Menteri Keuangan Nomor 523/KMK.04/1998, Peraturan Menteri Keuangan Nomor 150/PMK.03/2010, dan Peraturan Menteri Keuangan Nomor 139/PMK.03/2014 (PMK 139/2014), semuanya menggunakan judul yang sama yakni mengenai Penentuan Klasifikasi dan Besarnya Nilai Jual Obyek Pajak Sebagai Dasar Pengenaan Pajak Bumi dan Bangunan.

Adapun perubahan terakhir yang saat ini yang berlaku adalah Peraturan Menteri Keuangan Nomor 186/PMK.03/2019 tentang Penentuan Klasifikasi dan Besarnya Nilai Jual Obyek Pajak Sebagai Dasar Pengenaan Pajak Bumi dan Bangunan (PMK 186/2019). Akan tetapi pengaturan secara rinci terhadap PBB Minerba tersebut diatur dalam Peraturan Direktur Jenderal Pajak Nomor PER-47/PJ/2015 tentang Tata Cara Pengenaan Pajak Bumi dan Bangunan Sektor Pertambangan untuk Pertambangan Mineral dan Batubara (PDJP 47/2015) yang masih mengacu kepada PMK 139/2014 sebelumnya.

\subsection{Legitimasi PBB Minerba}

Sebagaimana telah disampaikan pada bagian sebelumnya, dasar hukum PBB Minerba tidak dapat ditemukan secara tersurat dalam tingkatan Undang-Undang sebagaimana diamanatkan oleh Konstitusi UUD 45. Baik Keputusan Menteri Keuangan ataupun Peraturan Direktur Jenderal Pajak tersebut secara jelas dalam bagian konsideran mengingatnya menyatakan UU PBB dan UU PBB perubahan sebagai dasar hukum pengaturan PBB Minerba tersebut. Akan tetapi, berbeda halnya dengan PMK 186/2019, justru PMK 139/2014 yang juga mencantumkan tambahan UU Minerba dan UU PDRD sebagai dasar hukumnya di bagian konsideran Mengingat.

Tidak dijelaskan alasan mengapa UU Minerba tidak lagi dijadikan dasar dalam PMK 186/2019 tersebut. Berbeda halnya dengan UU PDRD, yang mana dalam konsideran menimbang huruf $\mathrm{b}$ dijelaskan bahwa UU PDRD telah memisahkan kewenangan pemungutan dan pengelolaan Pajak Bumi dan Bangunan Perdesaan dan Perkotaan ke Pemerintah Daerah, maka kewenangan Direktorat Jenderal Pajak terkait Pajak Bumi dan Bangunan adalah mengelola Pajak Bumi dan Bangunan sektor Perkebunan, Perhutanan, Pertambangan, dan sektor lainnya. Hal tersebut justru sekaligus mengkonfirmasi dan memastikan bahwa PBB Minerba adalah bukan pajak yang diatur oleh UU PDRD.

Oleh karena itu, untuk dapat mempertahankan keabsahannya seturut dengan perintah Pasal 23A konstitusi UUD 45, maka legitimasi PBB Minerba hanya bersandar kepada Undang-Undang, dalam hal ini UU PBB dan UU PBB perubahan sebagaimana tercantum dalam konsideran PMK 186/2019, dengan tambahan UU Minerba sebagaimana tercantum dalam PMK 139/2014 yang menjadi dasar hukum PDJP 47/2015. Legitimasi tersebut mutlak diperlukan sesuai dengan ketentuan Pasal 8 ayat (2) juncto Pasal 8 ayat (1) UU 12/2011 yang menyatakan bahwa "Peraturan perundang-undangan diakui keberadaanya dan mempunyai kekuatan hukum mengikat sepanjang diperintahkan oleh Peraturan Perundang-undangan yang lebih tinggi atau dibentuk berdasarkan kewenangan."

Untuk keperluan tersebut di atas, maka selanjutnya saya akan melakukan pengujian terhadap PBB Minerba terhadap Undang-Undang sebagai berikut

\subsubsection{Legitimasi PBB Minerba dalam UU PBB/UU PBB Perubahan}


Dalam Pasal 1 ayat 1 UU PBB Perubahan mengubah isi Pasal 3 UU PBB yang memberikan kewenangan kepada Menteri Keuangan untuk menetapkan besaran Nilai Jual Obyek Pajak Tidak Kena Pajak setelah sebelumnya dalam UU PBB hanya menyebutkan nilai jual Bangunan Tidak Kena Pajak. Hal tersebut dapat diartikan bahwa Menteri Keuangan memiliki kewenangan tidak hanya dalam menentukan nilai pemotongan (yang tidak dikenakan pajak) jual bangunan saja melainkan terhadap seluruh obyek pajak. Akan tetapi tidak disebutkan secara jelas mengenai adanya kewenangan untuk menentukan atau menetapkan PBB atas barang tambang berupa mineral dan batubara. Dalam UU PBB juga secara eksplisit tidak disebutkan sama sekali mengenai jenis-jenis PBB termasuk sektor minerba.

Apabila kita perhatikan secara lebih mendalam, semangat lahirnya UU PBB adalah untuk penyederhanaan perpajakan, khususnya pajak kebendaan. Hal tersebut secara tegas tercantum dalam kalimat pertama dalam alinea keempat UU PBB yang menyatakan bahwa "Sistem perpajakan yang berlaku selama ini, khususnya pajak kebendaan dan kekayaan telah menimbulkan tumpang tindih antara satu pajak dengan pajak lainnya sehingga mengakibatkan beban pajak berganda bagi masyarakat." Dan selanjutnya dalam kalimat pertama alinea ketujuh menyatakan bahwa "Dengan mengadakan pembaharuan sistem perpajakan melalui penyederhanaan yang meliputi macam-macam pungutan atas tanah dan/atau bangunan, tarif pajak dan cara pembayarannya, diharapkan kesadaran perpajakan dari masyarakat akan meningkat sehingga penerimaan pajak akan meningkat pula." Maka apabila kita bandingkan visi dan misi UU PBB tersebut dengan PBB Minerba, maka akan ditemukan ketidaksesuaian yang mendasar, sekurang-kurangnya sebagai berikut:

i) Penyederhanaan sistem perpajakan. Sistem pembayaran PBB secara umum merupakan salah satu sistem perpajakan yang paling sederhana selain pajak kendaraan bermotor. Setiap awal tahun pemerintah cukup menerbitkan 1 lembar kecil Surat Pemberitahuan Pajak Terhutang Pajak Bumi dan Bangunan (SPPT PBB) yang wajib dibayarkan sebelum akhir bulan Agustus di tahun tersebut. Sistem tersebut sangat sederhana dan mudah dipahami sebagian besar anggota masyarakat pada umumnya. Hal tersebut jauh berbeda dengan PBB minerba yang menghitung kapitalisasi pendapatan bersih (pendapatan kotor dikurangi biaya-biaya produksi dan lain sebagainya). Sungguh sangat jauh dari cara penghitungan yang sederhana. Belum lagi pembagian areal Wilayah Izin Usaha Pertambangan (WIUP) yang terbagi-bagi atas areal yang dimanfaatkan untuk produksi, areal yang belum dimanfaatkan, areal cadangan produksi, areal pengaman, areal tidak produktif dan sebagainya. Sistem yang rumit dan tidak mudah dipahami oleh masyarakat umum.

ii) Tumpang tindih pajak. Bumi sebagai Obyek pajak PBB Minerba sangat berpotensi mengalami tumpang tindih pajak. Ketika kita berbicara mengenai areal dalam WIUP, kita tidak berbicara mengenai hamparan tanah kosong tidak bertuan. Pada umumnya dalam areal WIUP tersebut akan bersinggungan dengan adanya hutan (termasuk hutan produksi), dan tidak jarang juga dengan wilayah perkebunan, atau bahkan perumahan masyarakat. Dari situ terlihat jelas potensi yang sangat nyata akan terjadinya tumpang tindih antara PBB Minerba dengan PBB lain (rumah dan bangunan), atau dengan PBB sektor perkebunan, atau PBB sektor perhutanan. Apalagi dalam pelaksanaannya sangat sulit dilakukan pengukuran yang presisi atas suatu batas-batas tanah sebagai dasar penghitungan luasan obyek PBB dalam hal pertambangan. Pembukaan areal pertambangan (stripping) dan penimbunan tanah hasil stripping (Over Burden) seringkali mengubah dan menghilangkan batas-batas tanah sebagai batas obyek PBB. Itulah sebabnya dalam dunia pertambangan mengandalkan titik-titik koordinat satelit dan tidak bisa mengandalkan batas-batas alam ataupun batas-batas buatan manusia.

iii) Pajak berganda. Sebagai pajak kebendaan, PBB Minerba seharusnya hanya melekat kepada benda yang dimaksud. Berbeda dengan Pajak Penghasilan yang melekat 
terhadap pertambahan kekayaan Wajib Pajak. Adapun PBB bermaksud menghilangkan pajak berganda yang membebani masyarakat atas suatu obyek yang sama. PBB Minerba di satu sisi mengaku sebagai turunan dari PBB yang berarti seharusnya mengikat hanya terhadap kebendaan tertentu. Akan tetapi karena sifat dari barang tambang yang tidak pasti ada dalam suatu WIUP, maka posisi PBB Minerba menjadi gamang, hingga akhirnya bertansformasi sehingga harus menempuh formulasi perhitungan yang sangat rumit, yang justru menjauhkan diri dari sifat PBB yang sederhana sebagaimana telah saya bahas di atas. Perubahan ini sangat berpotensi menciptakan beban pajak berganda, karena PBB Minerba tidak murni hanya sebagai pajak kebendaan saja, melainkan juga mencakup aktivitas penambangannya. Hal ini juga dapat dikategorikan sebagai tumpang tindih akibat ketidakjelasan sifat dan karakteristik PBB Minerba apakah tetap menjadi pajak kebendaan atau bukan.

iv) Self-Assessment. Berbeda halnya dengan PBB pada umumnya, PBB Minerba melaksanakan sistem Self Assesment. Pada umumnya pengenaan PBB adalah menggunakan mekanisme Government-assessment, dimana kantor pertanahan melaporkan kepemilikan obyek pajak kepada kantor pajak, lalu kantor pajak menerbitkan Surat Pemberitahuan Pajak Terhutang Pajak Bumi dan Bangunan (SPPT PBB) pada setiap awal tahun. Dalam PBB Minerba, justru Wajib Pajak yang membuat Surat Pemberitahuan Obyek Pajak (SPOP) beserta Lampiran Surat Pemberitahuan Obyek Pajak (LSPOP), baru kemudian kantor pajak menerbitkan SPPT. Adapun salah satu lampiran dalam LSPOP adalah Rencana Kerja dan Anggaran Biaya (RKAB). Hal tersebut menegaskan bahwa dalam formulasi penghitungan tagihan pajak, PBB Minerba pada hakikatnya merupakan jenis pajak yang unik dan berbeda karena menerapkan prinsip yang bercampur antara pajak kebendaan dan pajak penghasilan. PBB Minerba tidak tepat dianggap sebagai pajak kebendaan karena menerapkan prinsip self-assessment, akan tetapi di lain sisi PBB Minerba juga tidak tepat dianggap sebagai pajak penghasilan karena masih berdasarkan suatu rencana belaka dalam RKAB yang masih sangat mungkin berbeda dengan kenyataan yang akan terjadi. John Steele Gordon berpendapat bahwa pajak seharusnya tidak menghambat perekonomian yang hasilnya kelak akan digunakan untuk membiayai pajak itu sendiri, sehingga dengan kata lain masyarakat seharusnya tidak perlu membuat keputusan yang bersifat ekonomis hanya karena pertimbangan pajak $^{1}$, dalam hal ini besarnya potensi pengenaan PBB Minerba sangat mungkin berpotensi menyebabkan Wajib Pajak untuk membatasi rencana produksi dalam RKAB guna dilaporkan dalam SPOP dan LSPOP, yang mana kelak justru dapat mengecilkan pajak penghasilan Wajib Pajak itu sendiri termasuk juga penerimaan negara dari royalti bagi hasil minerba. Karena sebagaimana kita ketahui bersama bahwa dalam suatu areal Wilayah Izin Usaha Pertambangan belum tentu pada seluruh arealnya mengandung mineral atau batubara, ${ }^{2}$ akan tetapi PBB menghitung berdasarkan luasan areal bumi, sehingga Wajib Pajak cenderung akan sangat berhati-hati dalam mengisi ataupun memuktahirkan data-data area produksi yang akan dilakukan guna menghindari besarnya tarif PBB Minerba yang ditagihkan.

Berdasarkan hal-hal tersebut di atas, maka saya berpendapat bahwa PBB Minerba belum mendapat legitimasi yang cukup dari UU PBB maupun UU PBB perubahan, karena selain daripada tidak disebutkan secara eksplisit oleh Undang-Undang tersebut, karakteristik PBB Minerba juga sangat berbeda dengan karakteristik PBB pada umumnya.

\subsubsection{Legitimasi PBB Minerba dalam UU Minerba/UU Minerba perubahan}

UU Minerba mengatur mengenai hal-hal yang berkaitan dengan usaha pertambangan mineral dan batubara. UU Minerba tidak mengatur mengenai PBB Minerba 
secara khusus. Demikian pula halnya dengan UU Minerba perubahan juga tetap tidak mengakomodir adanya PBB Minerba. Baik UU Minerba ataupun UU Minerba perubahan tidak memberikan legitimasi kepada Pemerintah Pusat (termasuk Menteri Keuangan) untuk menetapkan pajak (termasuk PBB Minerba). Hal tersebut nampak secara jelas dalam butirbutir kewenangan Pemerintah Pusat sebagaimana dicantumkan dalam kedua UndangUndang tersebut yang tidak mencantumkan kewenangan untuk menetapkan pajak atas barang tambang.

Dalam Pasal 6 ayat (1) huruf $m$ UU Minerba disebutkan bahwa "Pemerintah Pusat dalam pengelolaan pertambangan mineral dan batubara berwenang antara lain untuk melakukan perumusan dan penetapan penerimaan negara bukan pajak (PNBP) dari hasil usaha pertambangan mineral dan batubara." Hal tersebut diubah dalam Pasal 6 ayat (1) huruf o UU Minerba perubahan yang menyebutkan bahwa "Pemerintah Pusat dalam pengelolaan Pertambangan Mineral dan Batubara berwenang melakukan pengelolaan dan penetapan penerimaan negara bukan pajak (PNBP) dari hasil usaha pertambangan mineral dan batubara." Hal tersebut menunjukkan bahwa Pemerintah hanya berwenang menetapkan PNBP dan bukan pajak termasuk PBB Minerba. Hal tersebut sudah sesuai dengan Pasal 23A UUD 45 karena Pajak harus diatur dengan Undang-Undang, bukan sepihak oleh Pemerintah saja. Berbeda halnya dengan PNBP yang dapat ditetapkan secara sepihak oleh Pemerintah karena bersifat sebagai pembayaran jasa atau retribusi atas suatu pelayanan yang dilakukan oleh Pemerintah kepada masyarakat. Oleh karena itu, PBB Minerba juga tidak mendapatkan legitimasi baik dari UU Minerba maupun UU Minerba perubahan. Mungkin inilah yang menjadi salah satu alasan mengapa UU Minerba tidak dicantumkan sebagai dasar hukum PMK 186/2019, karena UU Minerba secara jelas tidak mendelegasikan kewenangan kepada Pemerintah Pusat dalam bentuk Pajak di sektor Minerba.

\subsubsection{Legitimasi kewenangan Menteri Keuangan menentukan PBB Minerba}

Setelah kita membahas mengenai ketiadaan delegasi kewenangan dari beberapa Undang-Undang tersebut di atas, maka untuk dapat memenuhi syarat formal dalam pungutan PBB Minerba sebagaimana mutlak diperlukan sesuai dengan ketentuan Pasal 8 ayat (2) juncto Pasal 8 ayat (1) UU 12/2011 tersebut di atas, maka harapan terakhir legitimasi kewenangan penetapan PBB Minerba ada di kewenangan yang dimiliki oleh pembentuknya, dalam hal ini Menteri Keuangan. Akan tetapi apabila kita kembali ke rumusan Pasal 23A konstitusi UUD 45, maka jelas disebutkan bahwa segala pajak diatur dengan Undang-Undang.

Oleh karena itu PBB Minerba hanya mendapat legitimasi jika diatur dengan Undang-Undang, bukan dengan PMK 186/2019 apalagi dengan PDJP 47/2015. Apalagi dalam konsideran menimbang huruf c PMK 186/2019 disebutkan "bahwa untuk memberikan kepastian hukum terkait pengenaan Pajak Bumi dan Bangunan yang diatur secara khusus dalam Kontrak Karya, Perjanjian Karya Pengusahaan Pertambangan Batubara, atau Izin Usaha Pertambangan Khusus Operasi Produksi, perlu menyelaraskan kewajiban pembayaran Pajak Bumi dan Bangunan yang diatur secara khusus tersebut dengan mekanisme penatausahaan Pajak Bumi dan Bangunan berdasarkan UndangUndang Nomor 12 tahun 1985 tentang Pajak Bumi dan Bangunan sebagaimana telah diubah dengan Undang-Undang Nomor 12 tahun 1994 tentang Perubahan atas UndangUndang Nomor 12 tahun 1985 tentang Pajak Bumi dan Bangunan." Rumusan kalimat "berdasarkan Undang-Undang" tersebut jelas masih mengacu kepada ketentuan Pasal 23 ayat 2 UUD 45 yang sudah diamandemen menjadi Pasal 23 A sejak 9 November 2001, akan tetapi masih diabaikan oleh Menteri Keuangan hingga 10 Desember 2019 dengan tetap dicantumkannya rumusan UUD 45 sebelum amandemen dalam PMK 186/2019 tersebut.

Mengenai kewenangan atributif yang dimiliki Menteri Keuangan jelas bukan kewenangan untuk menetapkan Undang-Undang, karena menurut Pasal 1 ayat 3 UU 
11/2011 Undang-Undang adalah merupakan kewenangan Dewan Perwakilan Rakyat dengan persetujuan bersama Presiden. Sehingga dengan tidak adanya kewenangan baik secara atributif ataupun delegatif yang dimiliki oleh Menteri Keuangan, maka saya berpendapat bahwa PBB Minerba yang diatur oleh Peraturan Menteri Keuangan adalah bertentangan dengan Pasal 23 A konstitusi UUD 45.

\section{KESIMPULAN}

Berdasarkan uraian-uraian tersebut di atas maka saya tiba pada suatu kesimpulan akhir bahwa hingga kini PBB Minerba masih berstatus inkonstitusional karena tidak sesuai dengan ketentuan Pasal 23 A konstitusi UUD 45. Untuk mendapatkan legitimasinya, PBB Minerba harus diatur dalam suatu Undang-Undang tersendiri, karena memiliki karakteristik yang unik tidak hanya sebagai pajak kebendaan yang menerapkan Government-assessment seperti misalnya PBB secara umum dan pajak kendaraan bermotor, melainkan juga memiliki sifat seperti pajak penghasilan yang menerapkan self-assessment dari Wajib Pajak. Karena sifatnya yang inkonstitusional, maka terdapat kemungkinan penerimaan dan pembayaran atas PBB Minerba sejak amandemen UUD 45 ditinjau kembali dan bila perlu dihentikan untuk sementara waktu, hingga ditetapkan dan diaturnya PBB Minerba dalam suatu Undang-Undang. Hal tersebut dapat membantu Pemerintah untuk menghindari gugatan dari para Wajib Pajak PBB Minerba yang merasa dirugikan akibat pungutan PBB Minerba yang inkonstitusional tersebut (AT).

\section{DAFTAR PUSTAKA}

Gordon, John S., "Down with Property Taxes", Wall Street Journal, Eastern Edition, Dow Jones\&Companies Inc., New York, 1998. Sumber diambil dari https://search.proquest.com/newspapers/down-withpropertytaxes/docview/398889990/se-2?accountid=17242, diunduh 5 Januari 2021.

Harvard Law Review, "Taxation. Particular forms of Taxation. Income Tax. Calculation of Income of Mining Company", Harvard Law Review, Vol.27, No.3, 1914.

Ismail, Tjip , "Bahan Ajar Pascasarjana FH UI, STHM, UNPAD, UBHARA”, Jakarta, 2020. , "Potret Pajak Daerah di Indonesia", edisi pertama, Prenadamedia Group, Jakarta, 2018.

McGee, Robert W.,'The Ethics of Tax Evation", Perspective in Theory and Practice, Springer, New York, 2012.

Pemerintah Indonesia, 1985, Undang-undang Nomor 12 tahun 1985 tentang Pajak Bumi dan Bangunan, Lembaran Negara Republik Indonesia tahun 1995, Nomor 68. Tambahan Lembaran Negara Republik Indonesia tahun 1985, Nomor 3312.

, 1994, Undang-undang Nomor 12 tahun 1994 tentang perubahan atas UndangUndang Nomor 12 tahun 1985 tentang Pajak Bumi dan Bangunan, Lembaran Negara Republik Indonesia tahun 1994, Nomor 62, Tambahan Lembaran Negara Republik Indonesia tahun 1994, Nomor 3569.

, 2009, Undang-Undang Nomor 4 tahun 2009 tentang Pertambangan Mineral dan

Batubara, Lembaran Negara Republik Indonesia tahun 2009, Nomor 4, Tambahan Lembaran Negara Republik Indonesia Nomor 4959. 2009, Undang-Undang Nomor 28 tahun 2009 tentang Pajak Daerah dan Retribusi Daerah, Lembaran Negara Republik Indonesia tahun 2009, Nomor 130, Tambahan Lembaran Negara Republik Indonesia Nomor 5049. , 2011, Undang-Undang Nomor 12 tahun 2011 tentang Pembentukan Peraturan Perundang-Undangan, Lembaran Negara tahun 2011 nomor 82, Tambahan Lembaran Negara tahun 2011 nomor 5234.

, 2020, Undang-Undang Nomor 3 tahun 2020 tentang Perubahan atas UndangUndang Nomor 4 tahun 2009 tentang Pertambangan Mineral dan Batubara, Lembaran Negara tahun 2020 nomor 147, Tambahan Lembaran Negara nomor 6525. 
Steinmo, Sven, “Analysis:The truth about taxes”, Challenge 38, no. 1 ,1995, Hal.57-58. Sumber http://www.jstor.org/stable/40722726, diunduh 6 Januari 2021 